\title{
Clinical significance and treatment of striae gravidarum during pregnancy: a review article
}

\author{
Ahmed M. Abbas ${ }^{1 *}$, Fatma M. Kamel², Safwat A. Salman' \\ ${ }^{1}$ Department of Obstetrics and Gynecology, Faculty of Medicine, Assiut University, Assiut, Egypt \\ ${ }^{2}$ Department of Obstetrics and Gynecology, Abnoub Central Hospital, Assiut, Egypt
}

Received: 03 November 2018

Accepted: 06 December 2018

*Correspondence:

Dr. Ahmed M. Abbas,

E-mail: bmr90@hotmail.com

Copyright: () the author(s), publisher and licensee Medip Academy. This is an open-access article distributed under the terms of the Creative Commons Attribution Non-Commercial License, which permits unrestricted non-commercial use, distribution, and reproduction in any medium, provided the original work is properly cited.

\begin{abstract}
Abdominal stretch marks found during pregnancy may be indicative of poor skin elasticity. One who does not have stretch marks may have better skin elasticity and may be less likely to tear perineal and vaginal tissue during vaginal delivery. Striae gravidarum (SG) is a common phenomenon of stretch marks observed during pregnancy that may be an indicator of poor skin elasticity. The type and amount of collagen in connective tissue are considered to determine the individual's elastic index. The skin surface is made up of a complex network of crossing thin lines. The twodimensional relationship between primary and secondary lines determines the skin texture and its grade of irregularity. SG is caused by changes in the structural connective tissue due to a hormonal elect on the alignment and reduced elastin and fibrillin in the dermis. Severity scoring of SG was observed using the numerical scoring system of Atwal. This score provides a rank based on observation of four areas in which SG is most commonly observed (abdomen, hips, buttocks, and breast).
\end{abstract}

Keywords: Pregnancy, Skin, Striae gravidarum, Topical

\section{INTRODUCTION}

Striae gravidarum (SG) is a common, disfiguring, gestational change that affects between $55 \%$ and $90 \%$ of women. ${ }^{1,2}$ SG presents as atrophic linear scars and can cause distress, often leading to a decrease in quality of life. ${ }^{3} \mathrm{SG}$ is a common phenomenon of stretch marks observed during pregnancy that may be an indicator of poor skin elasticity. The type and amount of collagen in connective tissue are considered to determine the individual's elastic index. The skin surface is made up of a complex network of crossing thin lines. The twodimensional relationship between primary and secondary lines determines the skin texture and its grade of irregularity. ${ }^{4} \mathrm{SG}$ is commonly present during pregnancy, though its severity is not considered as a medical condition in any clinical relevance for consideration in routine follow-up practice. It develops after 24 weeks of gestation. It has been reported that previous occurrence of striae on the breasts or thighs, family history of striae and race are significant predictors of striae development. Previous studies have showed that maternal age, prepregnancy and delivery BMI, neonatal birth weight, length and head circumference were independently associated with the occurrence of striae. ${ }^{5}$

SG first present as flat, pink-to-red bands (striae rubra or immature striae) that become raised, longer, wider, and violet-red. Over a period of months to years, the marks fade and become hypopigmented (striae alba or mature striae), appearing parallel to skin tension lines as scarlike, wrinkled, white, and atrophic marks6. SG can cause itching, burning, and discomfort and typically present on the breasts, abdomen, hips, and thighs. Up to $90 \%$ of SG 
appear in primigravidas. ${ }^{1}$ Onset has typically been reported in the late second and early third trimester; however, one study has demonstrated that $43 \%$ of women develop SG prior to 24 weeks of gestation. ${ }^{1}$

\section{SCORING OF SG}

Severity scoring of SG was observed using the numerical scoring system of Atwal. ${ }^{7}$ This scale provides a rank based on observation of four areas in which SG is most commonly observed (abdomen, hips, buttocks, and breast). The score includes the following criteria (a) the number of $S G$ at each body site $(0=$ no striae signs, $1=1-4$ striae, $2=5-10$ striae, $3=$ more than 10 striae) and (b) the color of the $\mathrm{SG}$ which ranges from pale to purple $(0=$ no redness, $1=$ pink, $2=$ dark red, $3=$ purple).

The final score for each body site, relating to number and color, ranges from 0 to 6 . Accordingly, the TSS (total striae score) for all four body sites ranges from 0 to 24 . Women having TSS score up to 12 were considered to be having mild striae, 13-18 TSS score indicated moderate striae and more than 18 TSS Score indicated severe striae. $^{7}$

\section{CLINICAL PICTURE AND HISTOPATHOLOGY OF SG}

Recent or immature SG are flattened areas of skin with a pink-red hue that may be itchy and slightly raised. Stretch marks then tend to increase in length and acquire a darker purple color. Over time, they become white, flat, and depressed. Histologically, earlier-stage or immature SG tend to appear pink or red in color (striae rubra) and over time and with atrophic changes attain a white color (striae alba). ${ }^{8}$

High-resolution epiluminescence colorimetric assessment of SG identified four distinct types: striae alba, striae rubra, striae caerulea, and striae nigra. The direct and indirect influences of melanocyte mechanobiology appear to have a prominent effect on the various color of SG. ${ }^{9}$ Recently it was demonstrated that SG are associated with loss of fibrillin, a fact that explains the counter replacement of fibrillin upon retinoic acid therapy. ${ }^{10}$

\section{RISK FACTORS}

The most common risk factors for SG include younger age, maternal and family history of SG, higher prepregnancy and pre-delivery weight, and higher birth weight. Most studies showed a statistically significant association between these risk factors and SG, however Findik et al, did not confirm pre-pregnancy weight or maternal age as a risk factor. ${ }^{11}$ Most studies also demonstrated that a history of striae on the breasts, hips, and thighs was associated with formation of SG. On the cotorary, a study of 299 Caucasian women showed that although striae on the breasts increased risk of SG, striae on the thighs decreased the risk of SG. However, confounding factors should be considered. Increased alcohol intake, decreased water consumption, decreased blood vitamin $\mathrm{C}$ levels, and expecting a male baby were also found to be more common among those women who developed SG in select studies. Even though it has been speculated that diabetes and increased serum glucose levels could play a part in the pathogenesis of SG, the studies included here did not reveal an association with diabetes or glycosylated haemoglobin levels. Studies were limited by study type, size, and patient population. ${ }^{11}$

\section{PREVENTION}

Preventative treatments have met with limited success. Creams that contain Centella asiatica extract, especially Trofolastin cream, are best supported by data for the prevention or reduction of the severity of SG. ${ }^{12}$ The application of almond oil, olive oil, or cocoa butter consistently failed to significantly lower the incidence of SG compared with placebo group. Two studies did find that when olive oil or almond oil were applied with a massage daily, they were associated with a lower incidence of SG development. However, these results may reflect the benefits of massage alone. ${ }^{13}$ Alphastria cream and verum cream, two proprietary creams that contain hyaluronic acid combined with various vitamins and fatty acids, were shown to significantly lower the incidence of SG in two studies. ${ }^{14}$ Hyaluronic acid, the active ingredient in both creams, is thought to increase resistance to mechanical forces and oppose atrophy through stimulation of fibroblast activity and collagen production. ${ }^{15}$

\section{TREATMENT}

Several medications have been proposed, yet no consistent modality is available. Some authors have suggested that time is the only treatment for SD and that it returns to normal over years, which is not true. It has always been suggested that effective treatment of SD be instituted during the active stage, well before the scarring process is complete. ${ }^{16}$

\section{Diet and exercise}

There is lack of data concerning the effect of diet and diet restrictions on stretch marks. Eighty women aged 24 to 53 participated in a 3-month weight-loss program;29 were on a diet, 31 were on a diet plus aerobic exercise program, and 20 obese women were on a diet plus a resistance exercise program. ${ }^{17}$ The data suggested that the degree of SG does not change with weight loss, regardless of the type of weight loss program.

\section{Topical therapies}

\section{Tretinoin}

The use of topical tretinoin has showed variable results, and some of the studies had proven the inefficacy of the 
vitamin A derivative in the treatment of SD, but most of the patients included in these early studies presented with old lesions that had evolved into whitish atrophic scars. ${ }^{10}$

More recently, tretinoin has been shown to improve the clinical appearance of stretch marks during the active stage (striae rubra), although with not much effect during the mature stage (striae alba). In the same study, 22 patients applied $0.1 \%$ tretinoin $(\mathrm{n}=10)$ or a placebo $(n=12)$ daily for 6 months to the affected areas. ${ }^{18}$

\section{Hydrant creams}

Anecdotal treatments are numerous and unproven. Despite the general understanding that proper hydration is necessary to maintain the integrity and barrier function of skin, little in the literature is available on the use of such creams in stretch mark prevention. Three studies involving 130 patients in total were found. ${ }^{19}$

The active creams in the studies described are not widely available, and it was not clear whether any ingredient was helpful. The lack of clarity on the studies and the scientific data available makes it difficult to conclude such creams are effective, and larger studies are needed to determine the efficacy and safety of such products in combating stretch marks. ${ }^{20}$ One study involved 80 women and investigated the effect of massage with a cream containing Centella asiatica extract, vitamin E, and collagen-elastin hydrolysates (Trofolastin, Novartis Barcelona, Spain) and its preventive effect on the development of stretch marks in pregnant women. ${ }^{21}$

\section{Topical oil massage and herbal}

\section{Topical remedies}

Some unconventional therapies and anecdotal reports recommend applying unproven oils and natural remedies to stretch marks. The underlying principle for this use would probably be keeping the skin well hydrated. Sweet almond oil, wheat germ oil, olive oil, avocado oil, and castor oil and applying seaweed wraps have these properties. $^{22}$ Other remedies such as comfrey, hypericum, maritime pine, equisetum, slippery elm, and wheat grass and eucalyptus tree oil are all used in creams or oils, but no efficacy studies have been performed to support these practices. $^{23}$

\section{Glycolic acid and Trichloroacetic acid}

Glycolic acid (GA) is an alpha hydroxyl acid. Although there are several reports on the clinical effects of GA in rejuvenation, peeling, and photoaging, no data on the effectiveness of GA to prevent stretch marks could be found in the scientific literature. No epidemiological study on the use of GA in pregnant women has been published. ${ }^{24}$ The precise mechanism of action of GA is still unknown because the biological effects of GA on cells has not been fully studied, although GA is reported to stimulate collagen production by fibroblasts and to increase their proliferation in vivo and in vitro. ${ }^{19}$ This mechanism can be useful for stretch mark treatments, but further investigations and studies are required to prove such theory. Trichloroacetic acid (TCA; 10-35\%) has been used for many years and is safe to use at low concentrations

\section{Lasers and light devices}

Of the many modalities used to ameliorate and improve stretch marks, lasers have recently become a popular therapeutic alternative. The 585-nm flashlamp-pumped pulsed-dye laser (PDL) is the most commonly reported laser used in treatment of SG. ${ }^{7}$ The use of ablative technologies such as the short pulse carbon dioxide and erbium-substituted yttrium aluminium garnet (YAG) enjoyed a brief popularity because of prolonged healing and pigmentary alterations, especially in darker skin tones. ${ }^{25}$ Newer applications of other laser modalities such as neodymium doped YAG (Nd:YAG), diode, and Fraxel are finding a way into treatment of stretch marks .

\section{Pulsed-dye laser}

The dilated blood vessels marked at the early stage of the stretch mark formation render the striaerubrae a good candidate for PDL. According to McDaniel and colleagues and Alster, a clinical improvement in immature SD is achieved after several courses of 585-nm flashlamp PDL therapy using dynamic cooling. McDaniel demonstrated that the optimal treatment fluence was 3 $\mathrm{J} / \mathrm{cm}^{2}$ using a $10-\mathrm{mm}$ spot size. ${ }^{19}$ This laser has been purported to increase the amount of collagen in the extracellular matrix. Jiminez and colleagues documented the effectiveness of the 585-nm flash lamp PDL in stretch marks of skin types I to IV and demonstrated that collagen changes precede any clinical significant change, although it was also reported that, for darker skin tones (IV-VI), laser treatment of SD should be avoided or used with great caution because of the possibility of pigmentary alterations after treatment. ${ }^{26}$

\section{Excimer laser}

Advances in technology have recently brought the308-nm xenon chloride $(\mathrm{XeCl})$ excimer laser to the laser arena. This newer technology allows treatment of focal areas with a wavelength close to that of traditional narrow-band ultraviolet B (UVB) light. ${ }^{27}$

\section{Funding: No funding sources \\ Conflict of interest: None declared}

Ethical approval: The study was approved by the Institutional Ethics Committee

\section{REFERENCES}

1. Picard D, Sellier S, Houivet E, Marpeau L, Fournet P, Thobois $\mathrm{B}$, et al. Incidence and risk factors for striae 
gravidarum. J Am Academy Dermatol. 2015;73(4):699700.

2. Rathore SP, Gupta S, Gupta V. Pattern and prevalence of physiological cutaneous changes in pregnancy: A study of 2000 antenatal women. Ind J Dermatol Venereol Leprol. 2011;77(3):402.

3. Park KK, Murase JE. Connective Tissue Changes. In: Kroumpouzos G, editor. Har/Psc e. Text Atlas of Obstetric Dermatology; 2013(1).

4. Halperin O, Noble A, Balachsan S, Klug E, LiebergallWischnitzer M. Association between severities of striae gravidarum and Obstetric Anal Sphincter Injuries (OASIS). Midwifery. 2017;54:25-8.

5. Betrán AP, Merialdi M, Lauer JA, Bing-Shun W, Thomas J, Van Look P, et al. Rates of caesarean section: analysis of global, regional and national estimates. Paediat Perinat Epidemiol. 2007;21(2):98113.

6. Schwingel AC, Shimura Y, Nakata Y, Kazunori O, Tanaka K. Exercise and striae distensae in obese woman. Med Scienc Sports Exercise. 2003;35(5):S33.

7. Atwal GS, Manku LK, Griffiths CE, Polson DW. Striae gravidarum in primiparae. British $\mathrm{J}$ Dermatol. 2006;155(5):965-9.

8. Shah DN, Recktenwall-Work SM, Anseth KS. The effect of bioactive hydrogels on the secretion of extracellular matrix molecules by valvular interstitial cells. Biomaterials. 2008;29(13):2060-72.

9. Johnston GA, Graham-Brown RA. The skin and disorders of the alimentary tract and the hepato biliary system kidney and cardiopulmonary systems. In: Gilchrest BA, Paller AS, Leffell DJ, Wolff K, Austen KF, Goldsmith LA, Katz SI, eds. Fitzpatrick's Dermatology in General Medicine. $7^{\text {th }}$ ed. New York: McGraw- Hill; 2007:1445-1460.

10. Garcia HL. Dermatological complications of obesity. Am J Clin Dermatol. 2002;3:497-506.

11. Findik RB, Hascelik NK, Akin KO, Unluer AN, Karakaya J. Striae gravidarum, vitamin $\mathrm{C}$ and other related factors. Int $\mathrm{J}$ Vitamin Nutrition Res. 2011;81(1):43-8.

12. García Hernández JÁ, Madera González D, Padilla Castillo M, Figueras Falcón T. Use of a specific antistretch mark cream for preventing or reducing the severity of striae gravidarum. Randomized, doubleblind, controlled trial. Int $\mathrm{J}$ Cosmetic Sci. 2013;35(3):233-7.

13. Timur Taşhan S, Kafkasli A. The effect of bitter almond oil and massaging on striae gravidarum in primiparaous Women. J Clinic Nursing. 2012;21(1112):1570-6.

14. Wierrani F, Kozak W, Schramm W, Grünberger W. Attempt of preventive treatment of striae gravidarum using preventive massage ointment administration. Vienna Clinic Weekly 1992;104(2):42-4.
15. Elsaie ML, Baumann LS, Elsaaiee LT. Striae distensae (stretch marks) and different modalities of therapy: an update. Dermatol Surg. 2009;35(4):563-73.

16. Elsaie ML, Baumann LS, Elsaaiee LT. Striae distensae (stretch marks) and different modalities of therapy: an update. Dermatol Surg. 2009;35(4):563-73.

17. Kim BJ, Lee DH, Kim MN, Song KY, Cho WI, Lee $\mathrm{CK}$, et al. Fractional photothermolysis for the treatment of striae distensae in Asian skin. Am J Clinic dermatol. 2008;9(1):33-7.

18. Hermanns JF, Piérard GE. High-resolution epiluminescence colorimetry of striae distensae. J Europ Academy Dermatol Venereol. 2006;20(3):282-7.

19. Karsai S, Roos S, Hammes S, Raulin C. Pulsed dye laser: what's new in non-vascular lesions?. J Europ Academy Dermatol Venereol. 2007;21(7):877-90.

20. Osman H, Usta IM, Rubeiz N, Abu-Rustum R, Charara I, Nassar AH. Cocoa butter lotion for prevention of striae gravidarum: a double-blind, randomised and placebo-controlled trial. BJOG: An Int J Obstet Gynaecol. 2008;115(9):1138-42.

21. Brinkhaus B, Lindner M, Schuppan D, Hahn EG. Chemical, pharmacological and clinical profile of the East Asian medical plant Centella aslatica. Phytomedic. 2000;7(5):427-48.

22. Okano Y, Abe Y, Masaki H, Santhanam U, Ichihashi M, Funasaka Y. Biological effects of glycolic acid on dermal matrix metabolism mediated by dermal fibroblasts and epidermal keratinocytes. Exp Dermatol. 2003;12:57-63.

23. Goldberg DJ, Marmur ES, Schmults C, Hussain M, Phelps R. Histologic and ultrastructural analysis of ultraviolet B laser and light source treatment of leukoderma in striae distensae. Dermatol Surg. 2005;31(4):385-7.

24. Keen MA. Striae distensae: What's new at the horizon? Brit J Med Pract. 2016;9(3):919.

25. Jimeénez GP, Flores F, Berman B, Gunja-Smith Z. Treatment of striae rubra and striae alba with the 585nm pulsed-dye laser. Dermatol Surg. 2003;29(4):362-5.

26. Trott J, Gerber W, Hammes S, Ockenfels HM. The effectiveness of PUVA treatment in severe psoriasis is significantly increased by additional UV 308-nm excimer laser sessions. Europ $\mathrm{J}$ Dermatol. 2008;18(1):55-60.

27. Alster TS. Laser treatment of hypertrophic scars, keloids, and striae. Dermatol clinics. 1997;15(3):41929.

Cite this article as: Abbas AM, Kamel FM, Salman SA. Clinical significance and treatment of striae gravidarum during pregnancy: a review article. Int J Reprod Contracept Obstet Gynecol 2019;8:368-71. 